\title{
The Effects of Various Types of Feed additives on The Chemical Composition of Local Chicken Meat (Gallus domestica)
}

\author{
Ali Makmur ${ }^{1}$, Sugito ${ }^{2}$ and Samadi ${ }^{3}$ \\ ${ }^{1}$ Master Program Veterinary Public Health Master Program Veterinary Faculty of Syiah Kuala University \\ ${ }^{2}$ Faculty of Veterinary Medicine of Syiah Kuala University \\ ${ }^{3}$ Animal Husbandry Program Faculty of Agriculture, Syiah Kuala University \\ Jl.Tgk Chik Pante Kulu No. 5 Darussalam Banda Aceh 23111 \\ *Corresponding author e-mail: alimakmur379@yahoo.co.id
}

\begin{abstract}
This study aims to determine the effect of giving various types of feed additives on the chemical composition value of super chicken chicken (Gallus domestica). This research is an experimental research using 20 super chicken chickens that come from chicken growth research (growth study). The design used in this study was Completely Randomized Design (RAL), consisting of 4 treatments and 5 replications. The treatment given was $(\mathrm{AO}=$ control (Vita chick 0.7 gram / liter; $\mathrm{A} 1=20 \mathrm{ml} /$ liter probio-FM; $\mathrm{A} 2=0.08 \% \mathrm{MOS}-$ oligosaccharide / $\mathrm{kg}$ of feed and $\mathrm{A} 3=$ herbal leuser $\mathrm{KI} 5 \mathrm{ml} /$ liter) is a 90-day old super chicken breast Chicken Variable observed moisture content, protein content and fat content The data obtained were analyzed by using vocabulary and tested further by Duncan's Multiple Range Test The results showed that treatment (P> $0,05)$ to the value of water content and protein of super chicken fowl. Average value of water content at each treatment A0 (69.81\%), A1 (70.74\%), A2 (71.56\%) and A3 (71.52\%) while mean value of protein A0 $(18.95 \%)$, A1 $(19.61 \%), A 2(19.01 \%)$ and $A 3(19.14 \%)) P<0.05)$ to the fat content of super chicken flesh, mean of fat content were A0 (2.02\%), A1 (1.49\%), A2 (1.37\%) and A3 (2.0\%).

Keywords: Feed additive, chemical composition, breast meat, super chicken
\end{abstract}

Abstrak. Penelitian ini bertujuan mengetahui pengaruh pemberian berbagai jenis imbuhan pakan terhadap nilai komposisi kimia daging ayam kampung super (Gallus domestica). Penelitian ini merupakan penelitian experimen dengan menggunakan 20 ekor ayam kampung super yang berasal dari penelitian pertumbuhan ayam (growth study). Rancangan yang digunakan dalam penelitian ini adalah Rancangan Acak Lengkap (RAL), terdiri dari 4 perlakuan dan 5 ulangan. Perlakuan yang diberikan adalah $\left(A_{0}=\right.$ kontrol (Vita chick $0.7 \mathrm{gram} /$ liter; $A_{1}=20 \mathrm{ml} /$ liter probio-FM; $A_{2}=0.08 \%$ MOS-oligosakarida $/ \mathrm{kg}$ pakan dan $A_{3}=$ herbal leuser $\mathrm{Kl} 5 \mathrm{ml} /$ liter). Sampel penelitian adalah Daging dada ayam kampung super umur 90 hari. Variabel yang diamati kadar air, kadar protein dan kadar lemak. Data yang diperoleh dianalisis dengan menggunakan sidik ragam dan di uji lanjut dengan uji Duncan (Duncan's Multiple Range Test). Hasil penelitian menunjukkan pemberian perlakuan tidak berpengaruh nyata $(P>0,05)$ terhadap nilai kadar air dan protein daging ayam kampung super. Rataan nilai kadar air pada setiap perlakuan $A_{0}(69,81 \%), A_{1}(70,74 \%), A_{2}(71,56 \%)$ dan $A_{3}(71,52 \%)$ sedangkan rataan nilai kadar protein $A_{0}(18,95 \%), A_{1}(19,61 \%), A_{2}(19,01 \%)$ dan $A_{3}(19,14 \%)$. Perlakuan berpengaruh sangat nyata $(P<0,05)$ terhadap nilai kadar lemak daging ayam kampung super. Rataan kadar lemak yaitu $A_{0}(2,02 \%), A_{1}$ $(1,49 \%), A_{2}(1,37 \%)$ dan $A_{3}(2,0 \%)$.

Kata kunci: imbuhan pakan, komposisi kimia, daging dada, ayam kampung super

\section{Introduction}

Kampung chicken is an Indonesian germplasm that is very potential to be developed, as it is geographically very supportive with the population spread almost in the whole countryside in Indonesia. Super village chicken is the result of crossing between the chicken with chicken type of laying chicken. Chicken crossing has grown faster than local chickens so-called super chicken. Super chicken breeding is more advantageous because it can be harvested in a shorter time can be harvested at the age of 2 months when compared with chicken in general that can be harvested at the age of 4 to 5 months (Ashar, 2016). Maintenance of super chicken has not paid attention to nutritional needs, because only use the rest of the kitchen and only added bran or rice bran, therefore the production and quality of meat is still not optimal, in order to increase 
the production and chemical composition of meat need to improve the quality of feed with the addition of feed additives to improving the quality of meat (Dewi, 2013). According to Torok et al. (2011) administration of antibiotics in the diet can increase beneficial bacteria and suppress harmful bacteria. Provision of antibiotics in animal feed can lead to resistance from harmful bacteria (pathogens), thus harmful to livestock health. Prohibition of antibiotic use in animal feed started in Sweden in 1986 (Dibner and Richards, 2005). In 1997, the World Health Organization (WHO) and the European Economic Community (MEE) included an agenda, which the use of antibiotics in animal feeds is a serious issue as it relates to the health of livestock consumer (meat, beef and egg).

Feed additives that can be used to increase the value of chemical composition, optimal and efficient productivity is to provide probiotics, prebiotics and various herbs derived from plants (WHO, 2002). Probiotics is a preparation consisting of living microorganisms to human health and livestock (Winarno, 1997). Probiotics can alter the intestinal microecology in such a way that beneficial microbes can thrive, the enzymes produced by microbes present in the probiotics of the amylase, protease and cellulase enzymes (Wang et al., 2008). According to Sudha et al. (2009) Lactobacillus bacteria found in probiotics are also able to bind fat and cholesterol contained in the bloodstream, then taken to the small intestine to be removed with feces. Prebiotics are fibers that can not be digested by monkeys (monogastric like chickens and pigs). The fiber can be a trigger for the increase of beneficial bacteria for livestock such as Lactobacillus and Bifidobacteria. Curcuminoid substances contained in herbs physically and chemically have potential as a feed additive, improve productivity, product quality, and livestock health (Integrated Laboratory of IPB, 2012). These compounds physiologically work to stimulate the secretion of large aqueous bile fluid so that the flow into the small intestine becomes larger and the absorption of feed in the small intestine is easier (Aziz, 2005). Curcumin also has a natural anti-oxidant function (Sharma et al., 2004).

Research related to feed additives has been widely practiced, but this study is limited to broilers (Awaad et al., 2011; Dizaji et al., 2012) or other types of livestock such as pigs (Papatsiros et al., 2011). While research using local chickens (kampung) is still very minimal, so the available data related to super chicken is still very limited. Therefore, research on the provision of various feed affects on chicken is considered necessary. This study is expected to obtain healthy chicken meat in terms of the value of chemical composition and is expected to contribute data for the development of chicken in terms of nutrition and public health. In addition, lately the demand for chicken meat increasingly days. Some consumers argue that the chicken has a different flavor compared with broiler chicken.

\section{Materials and Methods}

This research was conducted experimental method at Non-Ruminant Laboratory of Nutrition and Animal Feed Department Faculty of Animal Husbandry Andalas University 20 super chicken chickens from chicken growth research (growth study). Cages used 20 units measuring $1 \times 1 \mathrm{~m} 2$ (each unit of cages filled 10 chickens) each equipped with a feeding and drinking water. Chicken vaccinated ND strains of Lasota through eye drop on day 4, Gumboro vaccine on day 14 and ND Lasota strain via intramuscular injection on day 40. Treatment of the study: $A 0=$ control (Vita chick 0.7 gram / liter; $\mathrm{A} 1=20 \mathrm{ml} /$ liter of probio-FM; $\mathrm{A} 2=0.08 \%$ MOS-oligosaccharide $/ \mathrm{kg}$ of feed and $\mathrm{A} 3=$ herbal leucer KI $5 \mathrm{ml} /$ liter) each treatment consisted of 5 replication units. Chicken slaughtered 90 days old. Each unit of the cage samples taken as 1 tail (the number of samples 
per treatment as much as 5 tails). Furthermore breast meat is separated for analyzed water, protein and fat content using (Association of Official Analytical Chemists, 2005).

\section{Data Analysis}

The design used was Completely Randomized Design (RAL), consisting of 4 treatments and 5 replications. The measured variables are water content, protein and fat. The data were analyzed by using analysis of variance (ANOVA). If the results were significantly different then followed by Duncan's Multiple Range Test (Steel and Torrie, 1993) and (Kusriningrum, 2008).

\section{Results and Discussion}

\section{Water Content}

The results showed that the treatment did not give significantly different effect $(P>0.05)$ to the average of chicken water content of super chicken breast. The results showed that there was a tendency of decreasing of water content in treatment $A 0$ and $A 1$ although statistically did not give significantly different effect $(P>0,05)$ to chicken water content of chicken breast.
The results showed the high average water content in this study is estimated because the water content found in chicken breast meat is high when cutting. According to Aberle et al. (2001) the chemical composition of meat is 65$80 \%$ is water content, the chemical composition of water content in normal chicken meat ranges from $70 \%$ to $75 \%$. Furthermore Arbele et al. (2001) also mentions the water content may differ between muscles, the difference in water content in the animal body is affected by the variation in age and feed. Prior to the cutting all the treatment chickens are fasted for 12 hours. The absorption of water is then circulated by blood throughout the body tissues rapidly causing increased water absorption into the extracellular and intracellular spaces that allow for the increase of water content in chicken meat (Prasetyo et al., 2009).

The results showed that the $A 0$ treatment decreased the water content although it did not significantly affect it due to vitachick content having acidic $\mathrm{pH}$, which resulted in decreased $\mathrm{pH}$ of the meat. Due to the decrease in $\mathrm{pH}$, it causes cooking shrinkage and decreasing water holding capacity (Alvarado and Sams, 2003). Afrianti et al. (2013) states that water content is

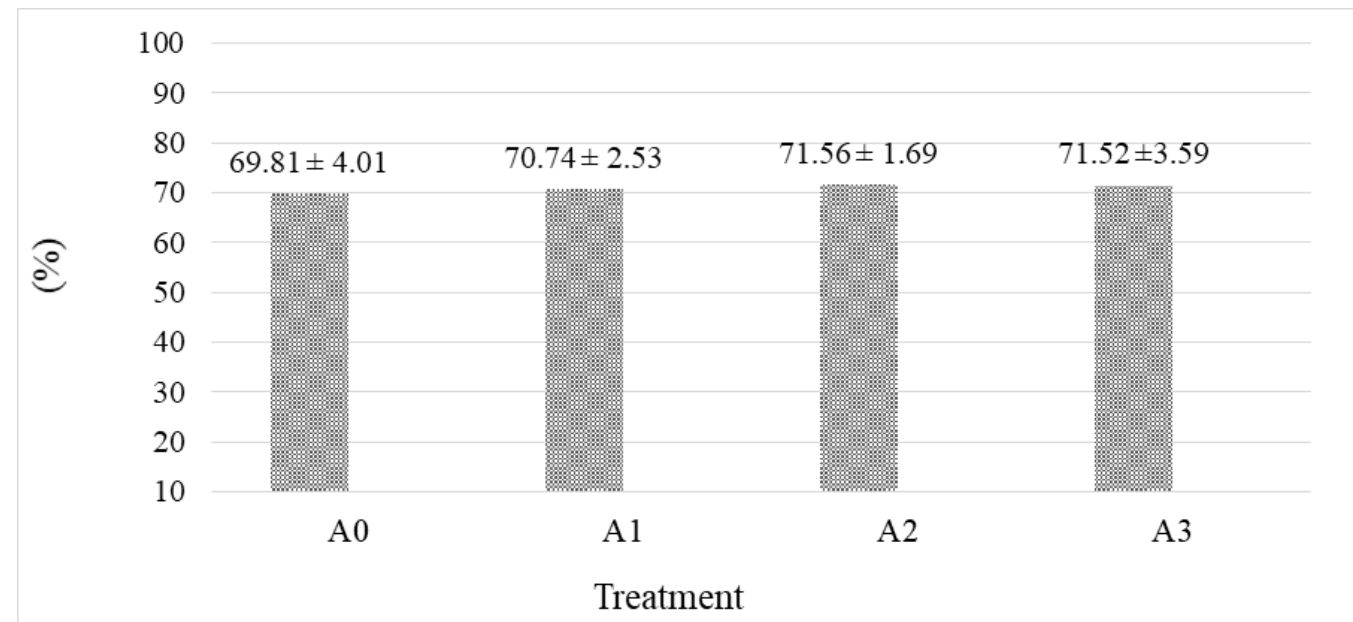

Figure 1. Average Water Content of Super Kampung Chicken Given Treatment of Various Types of Feed Additives. Description: $A 0=$ vita chick $0.7 \mathrm{~g} /$ liter water $) ; A 1=(20 \mathrm{ml}$ probio-FM +1 liter water $) ; \mathrm{A} 2=(0.08 \%$ MOS-oligosaccharides + commercial feed and $\mathrm{A} 3=(5 \mathrm{ml}$ herbs leuser $\mathrm{KI}+1$ liter water) superscript on image and mean row shows difference not significant $(P>0.05)$ 
one component in meat related to water binding power by meat proteins. According to Soeparno (2009) the water content of meat is influenced by the type of livestock, age, sex, feed and location and function of muscle parts in the body. Florence and Attwood (2011) add to that protein. is hydrophilic composed of hydrophilic amino acids, so it has a binding nature of water. This is what causes the breast meat has a protein content and water is higher than the thigh meat. The ability to retain water is an important factor, especially in meat that will be used in the food industry. The water holding capacity of the meat is the ability of the meat protein to bind water in the meat, so that the WHC can describe the level of protein deterioration of the meat. This is in accordance with Lawrie's (2003) statement which states that meat proteins play a role in the binding of meat water.

\section{Protein Levels}

The results showed that the addition of feed additives had no significant effect $(P>0.05)$ on protein content of super chicken chicken breast. It may be estimated in this study that there was no different protein value in the feed additive given to all treatments, so that in all treatments under normal circumstances. The results showed that the protein content of breast meat in super chicken ranged between $18.95 \%$ to $19.61 \%$ Figure 2 .

These results show almost the same as that of Pastariati et al. (2003) that the protein content of fresh chicken meat is $19,20 \%$. While Dewi et al. (2013) adds chicken protein content of $19.38 \%$ to $20.68 \%$. Xiao (2014) Increase the crude protein content of broiler chicken by 22,76-24,13\%. Hidayat (2017) states that protein intake is influenced by the amount of ration consumption, the higher the protein value the lower the conversion value of the ration spent. Furthermore Gultom (2014) states that high protein consumption will affect the intake of protein in meat and amino acids fulfilled in the body so that cell metabolism in the body takes place normally. While treatment with low protein content will have a low protein content of meat as well (Kartikasari et al., 2001). Suharyanto and Anang (2007) stated that chicken meat has good nutritional value and contains a very high protein that is $18.1 \%$.

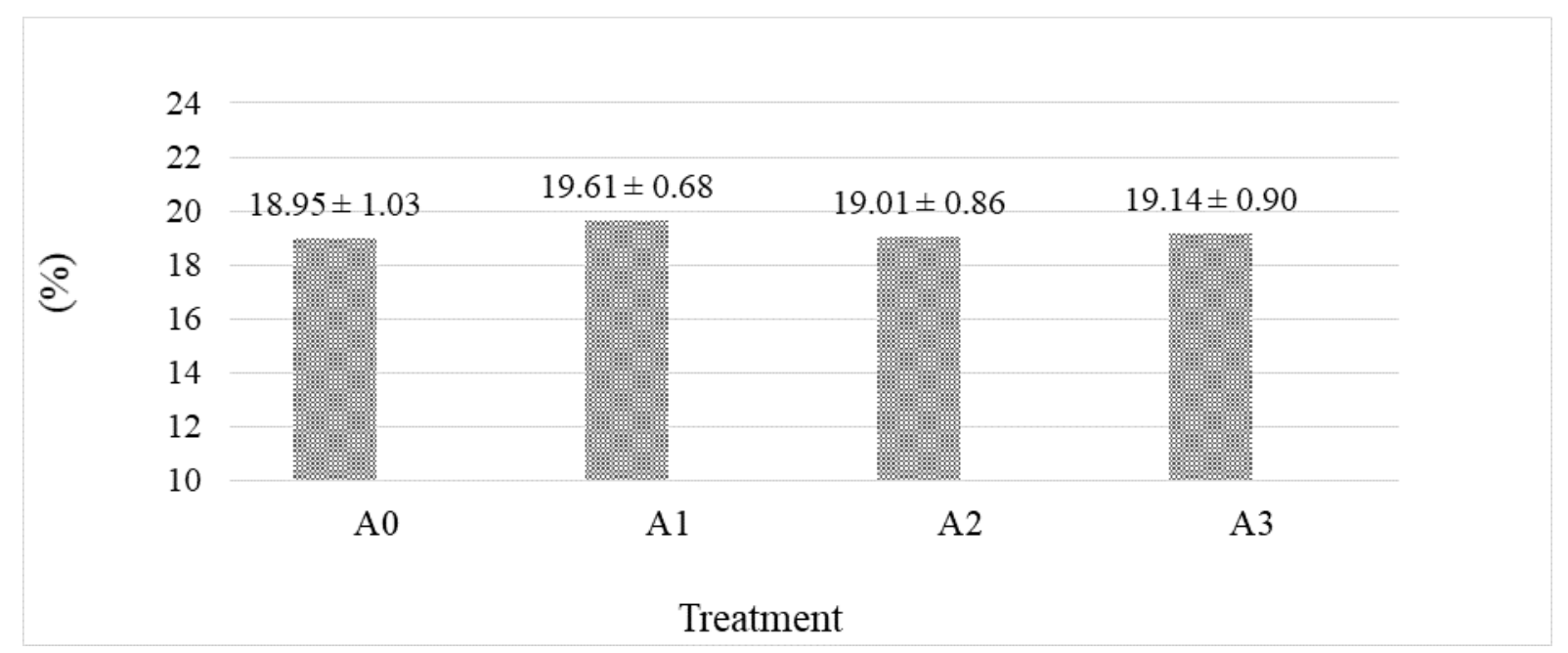

Figure 2. Average Protein Levels on Super Kampung Chicken Meat Given Treatment Different Types of Feed Additives. Description: * $A 0=$ vita chick $0.7 \mathrm{~g} /$ liter water $) ; A 1=(20 \mathrm{ml}$ probio$\mathrm{FM}+1$ liter water $) ; \mathrm{A} 2=(0.08 \%$ MOS-oligosaccharides + commercial feed and $\mathrm{A} 3=(5 \mathrm{ml}$ herbs leuser $\mathrm{KI}+1$ liter water)

* superscript on the average line drawing shows no significant difference difference $(P>0.05)$ 
In the treatment of chicken $\mathrm{A} 0$ given vitachick seen to have the lowest protein content value compared with treatment $\mathrm{A} 1, \mathrm{~A} 2$ and $\mathrm{A} 3$. This is possible because in this treatment the occurrence of gluconeogenesis is the formation of glucose from noncarbohydrates such as protein (Murray et al. 2009). Vitachik has an effect on increasing the number of ration conversion so that the increase of metabolic process causing the body to lose intake of glucose is great so that the body must meet the glucose from fat and protein so that there is a decrease in protein content.

\section{Fat Level}

The result of this research showed that feeding in feed and feed was very significant $(P$ $<0,05)$ to fat content of Fig. 3.

The results showed that there was a very significant difference $(P<0.05)$. Meat fat percentage ranged from $1.37 \%$ to $2.02 \%$. According to Dewi (2013) fat content of chicken meat ranges from $1.32 \%$ to $2.64 \%$. The results of fatty meat percentage in treatment $\mathrm{A} 1$ and A2 can be said slightly higher, compared with mean fat percentage of chicken meat in treatment $A 0$ and $A 3$. Based on the results of research Aberle et al. (2001) obtained the fat content of chicken meat including normal that is $1.2 \%$ to $12 \%$. further mentioned that the fat content of meat is influenced among others by the nation, the location of muscles, muscle types, sex and age of livestock. According to Hartono et al. (2013) the fat content is closely related to protein levels, if the protein content is high then the fat content will decrease. However, there is a tendency for chickens given probiotics and prebiotics to have lower fat content values than those treated with vitachick (AO) and $\mathrm{KI}(\mathrm{A} 3)$ leuser herbs. This suggests that probiotics and prebiotics can be used without increasing the fat content of super-chicken, precisely lower fat content.

Low levels of fat are also suspected probiotic and prebiotic contents affect the decrease in the conversion of rations that cause the decline in fat content in meat. This causes more energy needed by the chicken as a result there is no storage of excess energy. Low levels of fat in chicken fed with probiotics and prebiotics not only maintain a balance of gastrointestinal ecosystems, but also provide enzymes that are capable of digesting fat, protein and coarse fiber. According to Pothitirat and Gritsanapan (2006) The use of feed additives to livestock is caused by differences in the levels of active substances contained in the materials used. Provision of probiotics as feed additives will also produce more healthy meat for consumers because it does not contain residues and fat content and lower cholesterol (Kompiang, 2009). According to Mahfudz (2000) decreased fat content of chicken meat is also predicted because of the role of prebiotics in feed and probiotics in drinking water.

This study is consistent with what is reported by Daud et al., 2007 that the addition of probiotics in broiler ration affect the fat content of meat obtained, in prebiotics there are also two compounds namely MOS or fructooligosakarida and insulin. Both components, including these carbohydrates, are widely used to increase the levels of fiber that cannot be hydrolyzed (digested) by digestive enzymes. Probiotics allegedly also can maintain homeostasis that allows the mechanism of destruction or degradation of cholesterol by microorganisms in the intestines into bile acids kholat so that fat and cholesterol levels decreased (Fuller, 1992). As the results of research Afriani (2002) showed that the addition of probiotics in rations broiler chickens able to lower levels of fat and cholesterol meat.

In the treatment of $\mathrm{AO}$ and $\mathrm{A} 3$ there was a significant increase in fat content when compared to the treatment of addition of $A 1$ and prebiotic A2 This was possible in the addition of herbal leuser $\mathrm{KI}$ and vitachick, the ration consumed with excessive energy was stored in the form of fat so that the higher the. 


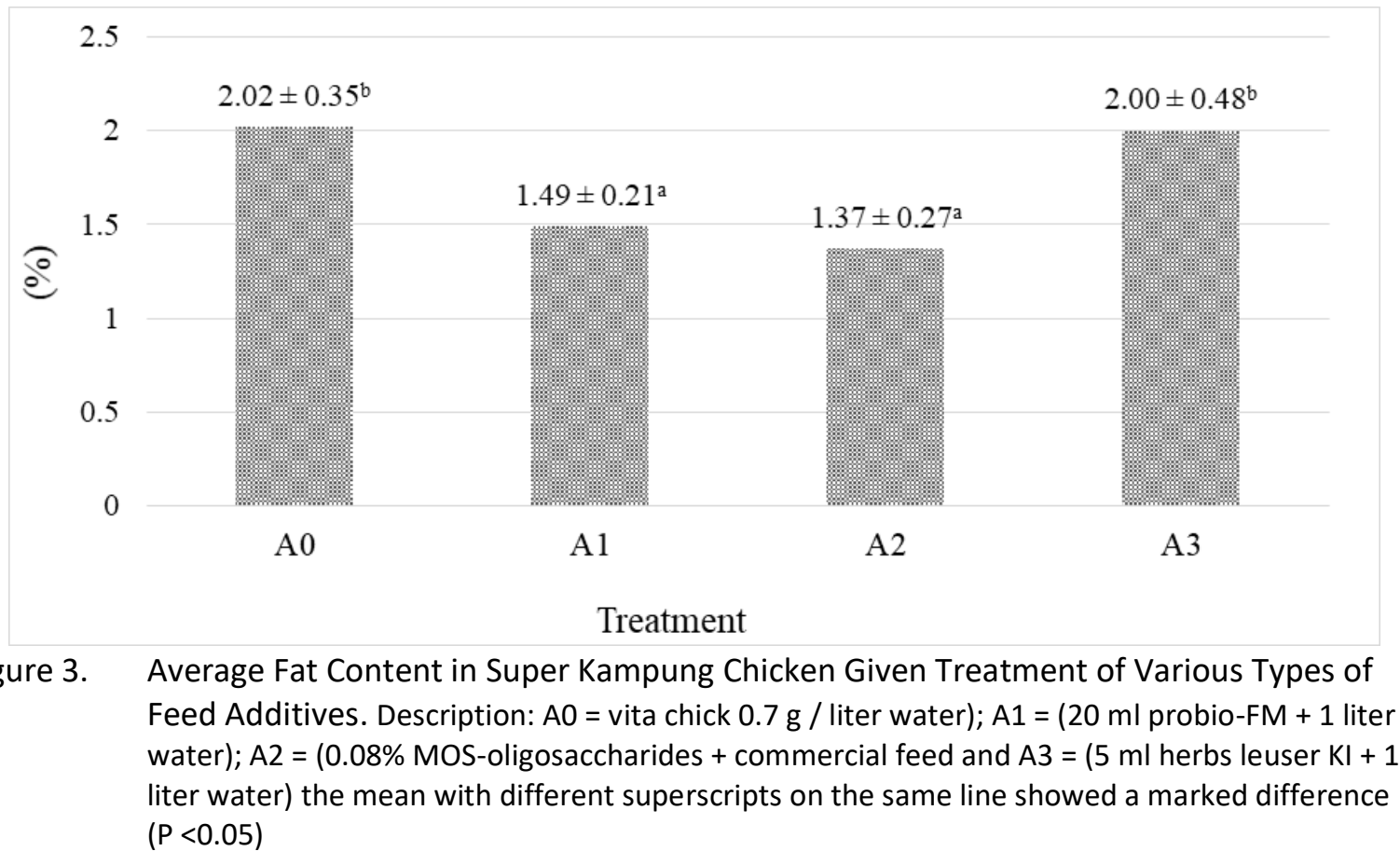

conversion of rations and the content energy in the ration, the higher the fat content in the body. This is in contrast to Agustina et al. (2014) the content of bioactive substances in herbs such as essential oil (fly oil) and curcumin function in improving the process of metabolism and fat loss in meat. Chemical compounds that exist in turmeric in herbs can reduce the fat in the body, play a role in the process of secretion of bile and pancreas released through the feces (Rahayu and Budiman, 2005). Meanwhile, according to Harden and Oscar (1993) the growth of fat tissue is the result of the accumulation of triglyceride in adipase. As a result, the higher the number of triglycerides in the chicken body, the higher the body fat of chicken meat. The accumulation of fat in broiler chickens is also affected by the fat in the ration. Described by Benerjee (1978) that most of the ration fat is triglyceride.

\section{Conclusions}

Based on the results of research that has been done can be concluded that the addition of various types of feed additives do not show the effect on the value of water and protein content of chicken meat, while the addition of various types of feed additives have an effect on the value of fat content of chicken chicken fat content is the lowest in the addition of probiotic treatment $\mathrm{A} 1$ ) and the addition of prebiotics (A2).

\section{Acknowledgement}

The authors would like to thank the directorate and community service directorate general of strengthening research and development of ministry of research, technology and higher education on funding so that this research can be completed.

\section{References}

Aberle EDCJ, H B Forest, MD Hedrick, Judge dan RA Merkel. (2001). The Principle of Meat Science, $\mathrm{WH}$, Freeman and Co, San Francisco.

Afriani, H. 2002. Pengaruh dosis kultur Bacillus spp dan Saccharomyces cerevisiae sebagai probiotik terhadap performan, kadar lemak dan kolesterol karkas ayam broiler. Tesis. Program Pascasarjana Universitas Pajajaran, Bandung.

Afrianti M, B Dwiloka, EB Setiani, 2013. An Effect of Soaking Senduduk (Melastoma malabathricum L.) leaf extract for Bacteria Total, $\mathrm{pH}$, and Water 
Content in Broiler Meat with During Storage. J. Pangan dan Gizi. 4 (7): 49-56.

Agustina L, W Ardiansya dan Jamila. 2014. Peran ramuan herbal Labio-1 terhadap performa dan infeksi salmonella pullorum pada broiler. http://repository.unhas.ac. id/handle Diakses 6 Mei 2018.

Alvarado, C. Z. and A.R. Sams. 2003. Injection marination strategies for remediation of pale, exudative broiler breast meat. Poult. Sci. 82(8): 1332-1336.

Ashar, M A Pagala dan T Saili. 2016. Characteristics of Qualitative Phenotype of Ayam Kampung Super. Jurnal Ilmiah Peternakan. 1(1):1-9.

Association of Official Analytical Chemist [AOAC].2005.Official Methods of Analysis (18 Edn). Association of Official Analytical Chemist Inc. Mayland. USA.

Awaad MHH, AM Atta, M Elmenawi, B Shalaby, A Abdel, GAK Median, K Ahmed, D Marzin, G Benzoni and DK Iskander. 2011. Effect of acidifiers on gastrointestinal tract integrity, zootechnical performance and colonization of Clostridium perfringens and aerobic bacteria in broiler chickens. J. Anim. Sci. 7(4). 11-24.

Aziz NK. 2005. Potensi temulawak dalam peningkatan produktivitas ternak. Poultry Indonesia. Edisi 302. hlm. 68-69.

Daud M, WG Piliang and IP Kompiang, 2007. Carcass percentage and quality of broilers given a ration containing probiotics and prebiotics. JITV. 12(3): 167-174.

Dewi SHC. 2010. Performans ternak ayam kampung yang dipelihara secara ekstensif di Kecamatan Fatuleu, Kabupaten Kupang, Nusa Tenggara Timur. Lingkungan Semiringkai. UNDANA Kupang. J. Agrisains. 1(2): 331-339.

Dewi SHC. 2013. Kualitas kimia daging ayam kampung dengan ransum berbasis konsentrat broiler. Program Studi Peternakan, Fakultas Agroindustri Universitas Mercu Buana Yogyakarta. J. Agrisains. 4 (6): 42-49.

Dibner, J.J. dan Richaards, J.D. 2005. Antibiotics growth promoters in agriculture. History on mode of action. Poult. Sci., 84: 634-643.

Dizaji BR, S Hejazi and A Zakeri. 2012. Effects of dietary supplementations of prebiotics, probiotics, synbiotics and acidifiers on growth performance and organs weights of broiler chicken. J. Exp. Bio. 2 (6):2125-2129.

Florence AT and D Attwood. 2011. Peptides, Proteins and Other Biopharmaceuticals. In: Physicochemical Principles of Pharmacy. Pharmaceutical Press Pub., London, United Kingdom. Page:451-476.
Fuller R. 1992. Probiotics: The Scientific Basis. Chapman and Hall, London.

Gultom. 2014. Kecernaan serat kasar dan protein kasar ransum yang mengandung pelepah daun kelapa sawit dengan perlakuan fisik, biologis, kimia dan kombinasinya pada domba. Tesis. Program Studi Peternakan Fakultas Pertanian Universitas Sumatera Utara.

Harden RL dan TP Oscar.1993. Thyroid hormone and growth hormone regulation of broiler adipocyte lipolysis. Poult. Sci. 72 (4): 669-676.S

Hartono EN, Iriyanti dan R Santosa, S Singgih. 2013. Penggunaan Pakan Fungsional Terhadap Daya Ikat Air, Susut Masak, dan Keempukan Daging Ayam Broiler. Jurnal Imu Peternakan. 1(1):10-19.

Hidayat C. 2015. Penurunan Deposit Lemak Abdominal pada Ayam Pedaging melalui Manajemen Pakan. Wartazoa. 25 (3): 125-13

Hidayat Z. 2017. Pengaruh penambahan Feed aditif dengan dosis berbeda dalam ransum terhadap performa ayam petelur. Skripsi Jurusan Peternakan Fakultas Pertanian Universitas Lampung.

Kartikasari LR Soeparno dan Setiyono. 2001. Komposisi kimia dan studi asam lemak daging dada ayam broiler yang mendapat suplementasi metionin pada pakan berkadar protein rendah. Buletin Peternakan 25 (1): 33-39.I

Kusriningrum RS. 2008, Buku Ajar Perancangan Percobaan, Fakultas kedokteran Hewan Universitas Airlangga, Dani Abadi, Surabaya.

Laboratorium terpadu IPB. 2012. Laporan pengujian laboratorium. Jawa Barat.

Lawrie RA. 2003. Meat Science. The $6^{\text {th }}$ ed. Terjemahan. A. Paraksi dan A. Yudha. Penerbit Universitas Indonesia. Jakarta.

Mahfudz LD. 2000. Efektivitas oncom tahu sebagai bahan pakan ayam broiler. Anim. Proc. 8(2).108114.

Murray RK, DK Granner and VW Rodwell. 2009. Biokimia harper. Edisi 27. Penerbit Buku Kedokteran EGC, Jakarta.

Papatsiros VG, G Christodoulopoulos dan LC Filippopoulos. 2011. The use of organic acids in monogastric animals (swine and rabbits). J. Cell. Anim. Bio. 6(10): 154-159.

Pothitirat W and W Gritsanapan. 2006. Variation of bioactive components in Curcuma longa in Thailand. Curr. Sci. 91 (10): 1397-1400.

Prasetyo A, Soeparno, E Suryanto dan Rusman. 2009. Chemical characteristics and microstructure of longissimus dorsi and biceps femoris muscle of glonggong beef cattle. Buletin Peternakan 33(1): 23-29.

Rahayu IHS dan C Budiman. 2005. Pemanfaatan tanaman tradisional sebagai feed additive dalam upaya menciptakan budidaya ayam lokal ramah 
lingkungan. Lokakarya Nasional Inovasi Teknologi Pengembangan ayam lokal. Departement IImu Produksi dan Teknologi Ternak: 126-131.

Sharma RA, SA Euden, SL Platton, DN Cooke, A Shafayat, HR Hewitt, TH Marczylo, B Morgan, D Hemingway, SM Plummer, M Pirmohamed, AJ Gescher and WP Steward. 2004, Phase I clinical trial of oral curcumin: biomarkers of systemic activity and compliance. Clin. Cancer Res. 10: 6847-6854.

Soeparno, 2009. Ilmu dan Teknologi Daging Gadjah Mada University Press, Yogyakarta.

Steel RGD and Torrie. 1993. Prinsip dan Prosedur Statistika Suatu Pendekatan Biometrik.. Terjemahan P.T. Gramedia, Jakarta.

Sudha MR, C Prashant, D Kalpana, B Sekhar and J Kaiser. 2009. Probiotics as Complementary Therapy for Hypercholesterolemia. J. Bio. Med.. 1 (4): rev.
Suharyanto dan Asep Anang. 2007. Panen Ayam Kampung Dalam 7 Minggu Bebas Flu Burung. Penebar Swadaya. Jakarta.

Torok, A.V. Allison,G.W., Percy, N.J., Ophel-Keller, K and Hughes, R.J. 2011. Influence of Antimicrobial Feed Additives on Broiler Commensal Posthatch Gut Microbiota Development and Performance. Applied and environmental microbiology, may 2011, p. 3380-3390 vol. 77, no. 10

Wang Y.B, J.R. Li, J. Lin 2008. Probiotics Cell Wall Hidropbobicity in Bioremediation of Aquaculture. Aquaculture 269: 349-352.

Winarno FG. 1997. Pobiotik dan Keamanan Pangan, Seminar. Universitas Gajah Mada. Yogyakarta.

Xiao J, Fang Z, Sun L. 2013. Kaempferitrin improves meat quality of broiler chickens. J. Anim. Sci. 58 (5): 227-231. 